Old Dominion University

ODU Digital Commons

2021

\title{
Diatom Hotspots Driven by Western Boundary Current Instability
}

Hilde Oliver

Weifeng G. Zhang

Walker O. Smith Jr.

Philip Alatalo

P. Dreux Chappell

Old Dominion University, pdchappe@odu.edu

See next page for additional authors

Follow this and additional works at: https://digitalcommons.odu.edu/oeas_fac_pubs

Part of the Climate Commons, and the Oceanography Commons

\section{Original Publication Citation}

Oliver, H., Zhang, W. G., Smith Jr., W. O., ... Stanley, R. H. R., Zhu, Y., \& McGillicuddy Jr., D. J. (2021). Diatom hotspots driven by western boundary current instability. Geophysical Research Letters, 48(11), 1-10, Article e2020GL091943. https://doi.org/10.1029/2020GL091943

This Article is brought to you for free and open access by the Ocean \& Earth Sciences at ODU Digital Commons. It has been accepted for inclusion in OES Faculty Publications by an authorized administrator of ODU Digital Commons. For more information, please contact digitalcommons@odu.edu. 


\section{Authors}

Hilde Oliver, Weifeng G. Zhang, Walker O. Smith Jr., Philip Alatalo, P. Dreux Chappell, Andrew J. Hirzel, Corday R. Selden, Heidi M. Sosik, Rachel H.R. Stanley, Yifan Zhu, and Dennis J. McGillicuddy Jr. 


\section{Geophysical Research Letters}

\section{RESEARCH LETTER \\ 10.1029/2020GL091943 \\ Key Points: \\ - Highly productive subsurface diatom hotspots were observed on the Mid- Atlantic Bight continental slope in July 2019 \\ - The hotspots were associated with the temperature-salinity signature of Gulf Stream (GS) water \\ - The hotspots appear to have resulted from the onshore intrusion and upwelling of GS water from a GS meander}

Supporting Information:

Supporting Information may be found in the online version of this article.

Correspondence to:

H. Oliver,

holiver@whoi.edu

Citation:

Oliver, H., Zhang, W. G., Smith, W. O., Alatalo, P., Chappell, P. D., Hirzel, A. J., et al. (2021). Diatom hotspots driven by western boundary current instability. Geophysical Research Letters, 48, e2020GL091943. https://doi. org/10.1029/2020GL091943

Received 3 DEC 2020

Accepted 22 MAR 2021

(C) 2021. American Geophysical Union. All Rights Reserved.

\section{Diatom Hotspots Driven by Western Boundary Current Instability}

\author{
Hilde Oliver $^{1}\left(\mathbb{D}\right.$, Weifeng G. Zhang ${ }^{1}\left(\mathbb{D}\right.$, Walker O. Smith Jr. $^{2,3}\left(\mathbb{D}\right.$, Philip Alatalo ${ }^{1}$ (D), \\ P. Dreux Chappell ${ }^{4}$ iD, Andrew J. Hirzel ${ }^{1}$ (D), Corday R. Selden ${ }^{4}$ (D), Heidi M. Sosik ${ }^{1}$ (i), \\ Rachel H. R. Stanley ${ }^{5}$ (D), Yifan Zhu ${ }^{4}$ (D), and Dennis J. McGillicuddy Jr. ${ }^{1}$ (D)
}

${ }^{1}$ Woods Hole Oceanographic Institution, Woods Hole, MA, USA, ${ }^{2}$ Virginia Institute of Marine Science, College of William \& Mary, Gloucester Point, VA, USA, ${ }^{3}$ School of Oceanography, Shanghai Jiao Tong University, Shanghai, People's Republic of China, ${ }^{4}$ Department of Ocean and Earth Sciences, Old Dominion University, Norfolk, VA, USA, ${ }^{5}$ Department of Chemistry, Wellesley College, Wellesley, MA, USA

\begin{abstract}
Climatic changes have decreased the stability of the Gulf Stream (GS), increasing the frequency at which its meanders interact with the Mid-Atlantic Bight (MAB) continental shelf and slope region. These intrusions are thought to suppress biological productivity by transporting low-nutrient water to the otherwise productive shelf edge region. Here we present evidence of widespread, anomalously intense subsurface diatom hotspots in the MAB slope sea that likely resulted from a GS intrusion in July 2019. The hotspots (at $\sim 50 \mathrm{~m}$ ) were associated with water mass properties characteristic of GS water $(\sim 100 \mathrm{~m})$; it is probable that the hotspots resulted from the upwelling of GS water during its transport into the slope sea, likely by a GS meander directly intruding onto the continental slope east of where the hotspots were observed. Further work is required to unravel how increasingly frequent direct GS intrusions could influence MAB marine ecosystems.
\end{abstract}

Plain Language Summary As the climate has warmed, the changing large-scale circulation of the northwest Atlantic has resulted in increasing western boundary current instability. As a consequence, onshore intrusions of Gulf Stream (GS) water into the Northeast U.S. continental shelf have become increasingly frequent. The impacts of this shift on marine ecosystems have yet to be resolved. While these intrusions of low-nutrient GS water have been thought to potentially diminish biological productivity, we present evidence of an unexpectedly productive subsurface diatom bloom resulting from the direct intrusion of a GS meander toward the continental shelf. These results suggest that changing large-scale circulation has consequences for regional productivity that are not detectable by satellites by virtue of their occurrence well below the surface.

\section{Introduction}

The Mid-Atlantic Bight (MAB) region of the Northeast U.S. continental shelf is one of the world's most productive marine ecosystems (O'Reilly \& Busch, 1984; O'Reilly et al., 1987) and is critical to regional commercial fisheries (Sherman et al., 1996). Unlike the MAB continental shelf and shelfbreak front (e.g., Ryan et al., 1999; Zhang et al., 2013), the MAB slope sea to the south is generally characterized by lower biomass (e.g., Xu et al., 2011), with summer subsurface chlorophyll (Chl) maximum layers dominated by nanoplankton (O'Reilly \& Zetlin, 1998).

MAB net community production is highly sensitive to ocean circulation (Friedrichs et al., 2019), but the response of the region's marine ecosystems to recent changes in northwest Atlantic circulation remains poorly constrained. Over the past two decades, the destabilization point of the Gulf Stream (GS) has shifted westward, resulting in more vigorous meandering of the GS south of the MAB (Andres, 2016). Consequently, the influence of the GS on the MAB has increased through both direct intrusion of GS water (Gawarkiewicz et al., 2012) and indirect interactions associated with more frequent GS shedding of anticyclonic warm-core rings (WCRs) (Gangopadhyay et al., 2019; Gawarkiewicz et al., 2018). To first order, increasing intrusions of GS water have been expected to decrease slope sea biological productivity (e.g., Brown et al., 1985; Zhang \& Gawarkiewicz, 2015) as surface GS water is more oligotrophic than the slope (Brown et al., 1985; Olson et al., 1994). Here, we show observations from the MAB slope sea suggesting that the opposite can also occur. 

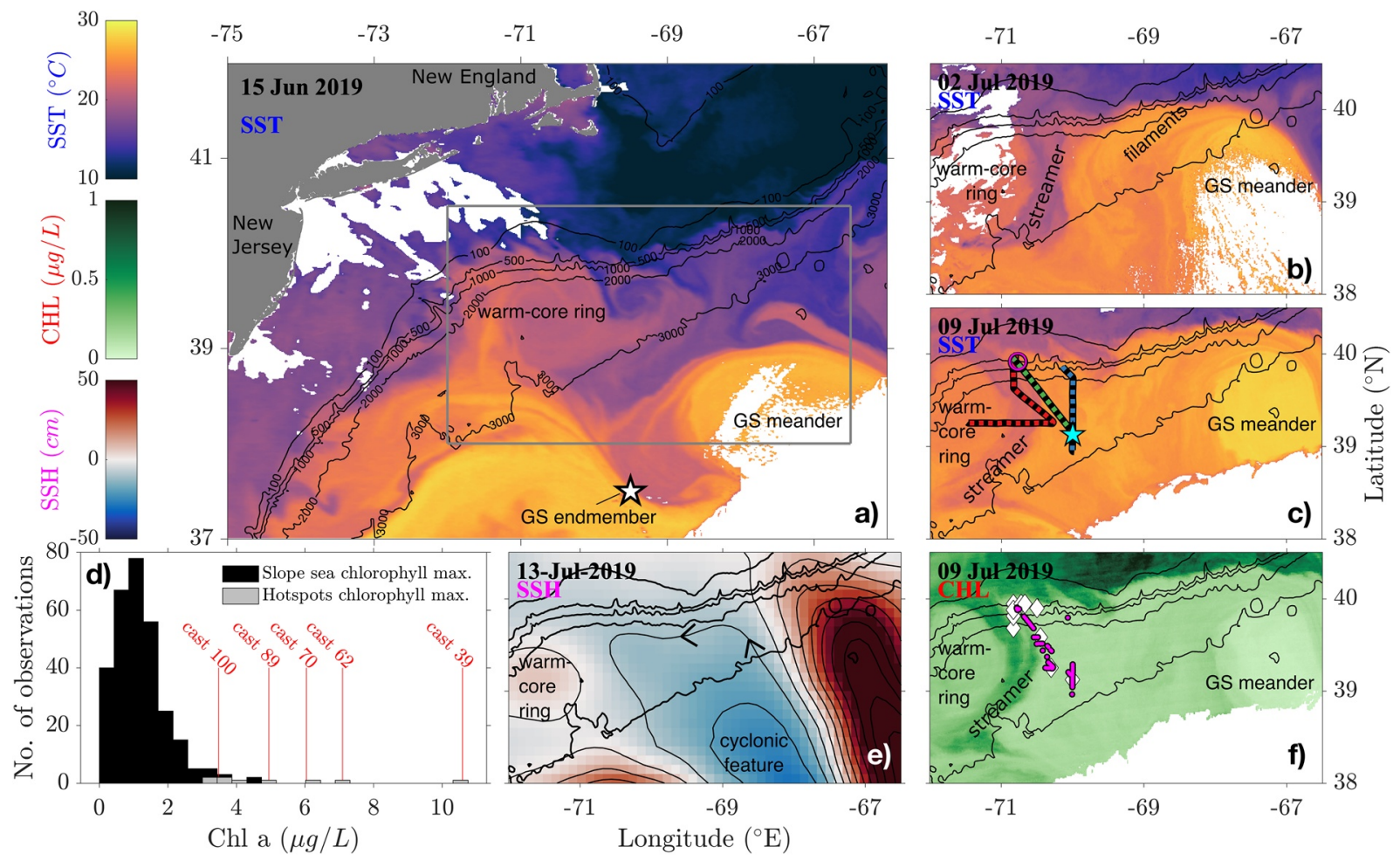

Figure 1. (a-c) Sea surface temperature (SST) showing the evolution of large-scale features in the Mid-Atlantic Bight (MAB) in the weeks leading up to TN368; (d) histogram of historical slope sea (depth $>200 \mathrm{~m}$ ) chlorophyll (Chl) maxima measurements made from June-September from a MAB climatology (Zhang et al., 2013; Figure S1), including TN368 profiles (black bars), plotted with a histogram of TN368 hotspot Chl maximum concentrations (gray bars), with cast 100 and casts with Chl maxima $>4 \mu \mathrm{g} / \mathrm{L}$ highlighted; (e) 7-day composite sea surface height (SSH) from Aviso+ with $10 \mathrm{~cm}$ contours; (f) VIIRS NOAA-20 1-day 1-km composite Chl during TN368. In (a), the white star shows location of the Gulf Stream (GS) endmember profile used to initialize the 1D model. In (c), striped lines indicate Video Plankton Recorder (VPR) tows 2 (red), 7 (blue), and 8 (green) shown in Figure 2; cyan star shows the location of station SLP (Cast 100), used for 1D model validation; magenta circle at the intersection of VPR tows 2 and 8 shows the location of REMUS mission 4a (at a much smaller scale). In (e), arrows on the cyclonic feature show a possible transport pathway of GS water to the edge of the shelf and hotspot region. In (f), white diamonds show locations of conductivity-temperature-depth casts at a hotspot, and magenta dots show locations of hotspots found by the VPR.

In July 2019, we observed unexpected diatom hotspots at the base of the euphotic zone in the slope sea with Chl concentrations several times higher than the climatological mean. We hypothesize that this feature resulted from the northward intrusion of a GS meander into the slope sea and was fueled by nutrients upwelled in GS water. Observatory data show occurrences of similar subsurface blooms in the slope sea in other recent years. Such widespread subsurface blooms of siliceous plankton may be important when considering the impacts of changing large-scale circulation patterns on MAB regional productivity.

Details of our methods are provided in Text S1-S12.

\section{Subsurface Diatom Hotspots Found at High Salinities}

In July 2019, the $R / V$ Thomas $G$. Thompson cruise TN368 embarked to investigate the dynamics controlling primary productivity in the northern MAB shelfbreak region. In addition to traditional conductivity-temperature-depth (CTD) rosette sampling, high-resolution surveys of physical and biological properties in the upper water column $(<100 \mathrm{~m})$ were conducted with a Video Plankton Recorder (VPR) and autonomous underwater vehicle REMUS 600.

At the time of the cruise (July 6-18), a WCR was impinging on the MAB shelfbreak and entraining cooler shelf water at its periphery, drawing it into the warmer slope sea by its anticyclonic (clockwise) motion. This created a "streamer" of shelf water (e.g., Morgan \& Bishop, 1977) at the eastern edge of the WCR (Figures 1b, 1c, and 1f). About $350 \mathrm{~km}$ to the east (at $67 \mathrm{~W}$ ), a meander of the GS was transporting warmer 

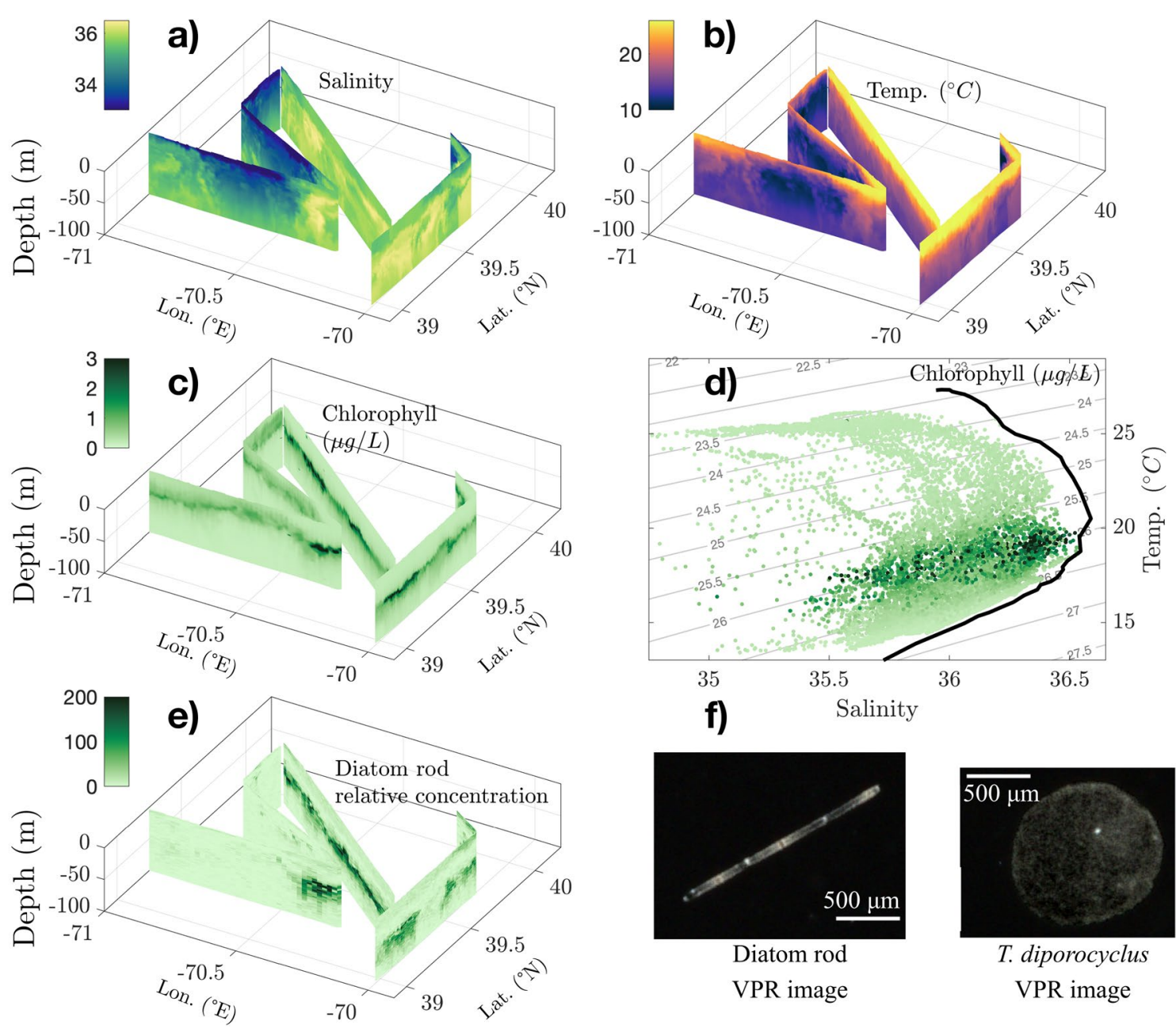

Figure 2. Video Plankton Recorder (VPR) tows 2, 7, and 8. (a) Salinity; (b) temperature; (c) chlorophyll (Chl) concentration; (d) corresponding T-S diagram from the tows, colored by Chl concentration, with the black line showing the Gulf Stream T-S profile from $69.5 \mathrm{E}, 37 \mathrm{~N}$ from 1/10 summer objectively analyzed climatological means from the National Centers for Environmental Information Northwest Atlantic Regional Ocean Climatology, with the same Chl color bar used in (c); (e) relative diatom rod concentration; (f) two example VPR images: one classified as a "diatom rod," the other a T. diporocyclus diatom colony.

GS water northward toward the shelfbreak. During the weeks preceding sampling, the WCR was migrating westward (e.g. Nof, 1983), while the meander was traveling eastward. In the broadening area between these anticyclonic features, satellite altimetry revealed a cyclonic (counterclockwise) feature (Figure 1e).

Directly east of the streamer, unexpected Chl hotspots were detected at ca. $50 \mathrm{~m}$ below the surface (Figure 2). These subsurface features were found in the oligotrophic slope sea east of the WCR in the following locations: (a) A narrow band on the eastern edge of the shelf water streamer, (b) along the offshore edge of the shelfbreak, and (c) within the cyclonic feature between the WCR and the GS meander (Figures 1e and 1f). We encountered hotspots at $\sim 1 / 3$ of all VPR profiles in the slope sea east of the WCR (Figure 4, VPR tows 7 and 8). The hotspots occurred where salinities were greater than 35.6 (Figure 2). This high-salinity water associated with the hotspots had water mass properties of GS water typically found hundreds of kilometers south of the shelf-break and $50 \mathrm{~m}$ deeper in the water column (Figure S2). This GS water (salinity $>35.6$ ) was ubiquitous in the slope sea sampled during TN368: It was present within the top $50 \mathrm{~m}$ at $>99 \%$ of all slope sea profiles (VPR tows 7 and 8).

The hotspots were highly anomalous compared to typical Chl levels in the slope sea. The hotspot Chl concentrations were 1.9-8.8 standard deviations greater than the mean slope sea climatological Chl maximum $\left(1.3 \pm 1.1 \mu \mathrm{g} \mathrm{L}^{-1}\right)$, with $4 / 10$ of the hotspot casts reaching a Chl maximum concentration greater than the 

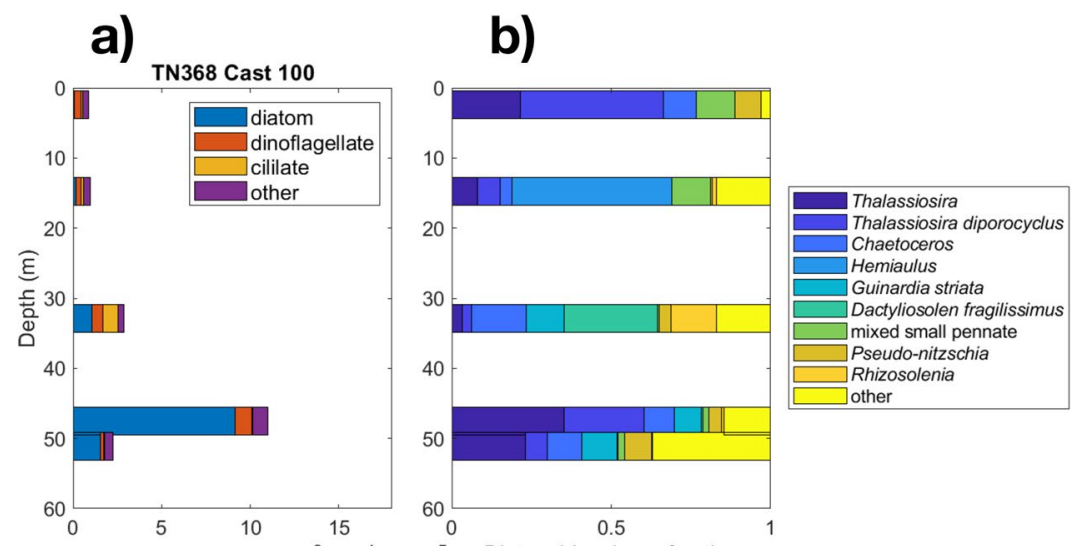

Biovolume concentration $\left(\mu \mathrm{m}^{-3} \mathrm{~mL}^{-1}\right) \times 10^{-5} \quad$ Diatom biovolume fraction

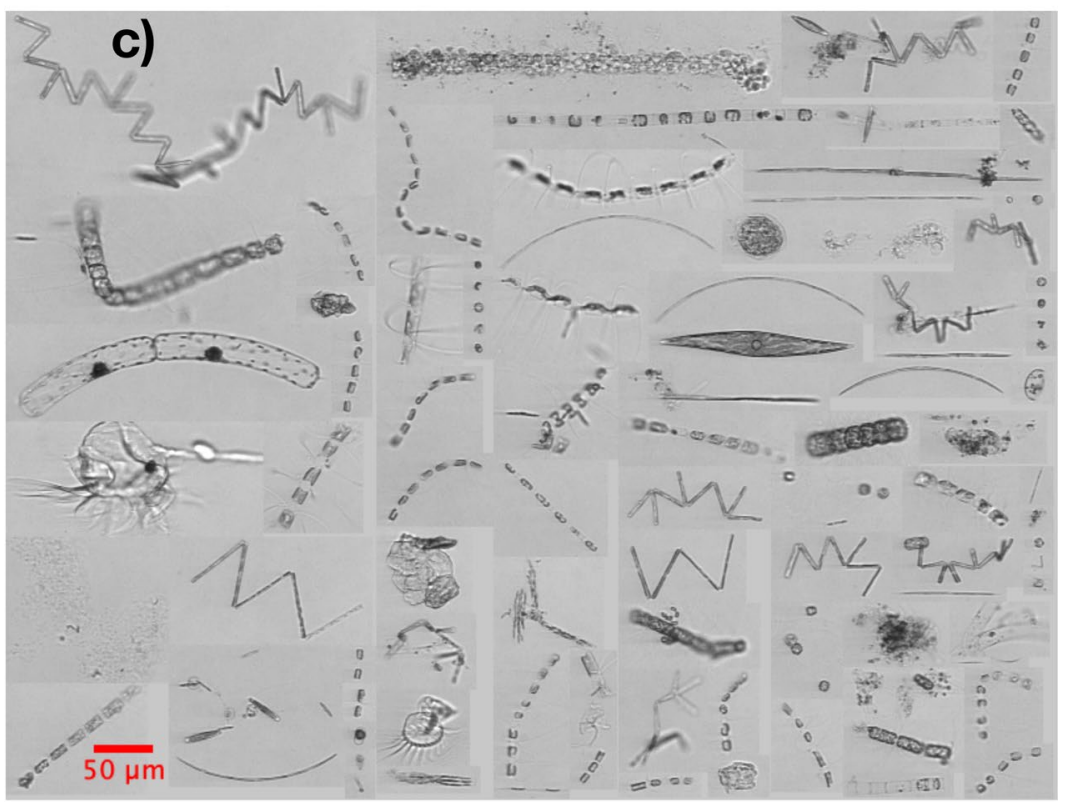

Figure 3. Imaging FlowCytobot (IFCB) classification and image subset from station SLP (Cast 100). (a) The relative biovolume of major phytoplankton groups at depths sampled; (b) the diatom taxa comprising the diatom assemblages in (a); (c) a collage of example IFCB images subset from $51 \mathrm{~m}$ depth.

highest summer slope sea Chl maximum documented in the World Ocean Database (Figure 1d). Usually, in oligotrophic waters, the depth of the Chl maximum tends to be decoupled from the maximum in phytoplankton biomass due to photoacclimation (Cullen, 2015; Fennel \& Boss, 2003). The hotspots we observed bore high concentrations of particulate organic nitrogen and carbon, however, suggesting that they were high in biomass. They also corresponded to elevated biogenic silica concentrations and increased silicate drawdown relative to nitrate and ammonium, indicative of high diatom biomass (Figure S3).

Imaging FlowCytobot (IFCB) images affirmed that the plankton community within the Chl hotspots was dominated by diverse assemblages of diatoms (Figure 3). VPR image classification revealed that the Chl hotspots corresponded to large concentrations of rod-shaped diatoms (Figure 2e), as well as an abundance of colonial phytoplankton identified as Thalassiosira sp. from IFCB images. Accordingly, the diatom 18S rDNA pool at all hotspot sites was dominated (30\%-73\% relative abundance, Figure S5) by the mucilaginous, colony-forming diatom Thalassiosira diporocyclus, which has been previously observed in association with GS WCRs (Fryxell et al., 1984). Numerous centric diatoms and chain-forming, pennate diatoms were also present within the hotspots (Figure 3). T. diporocyclus was not observed on the shelf, but was present at lower relative abundance $(\sim 10 \%)$ in nonhotspot slope waters. 

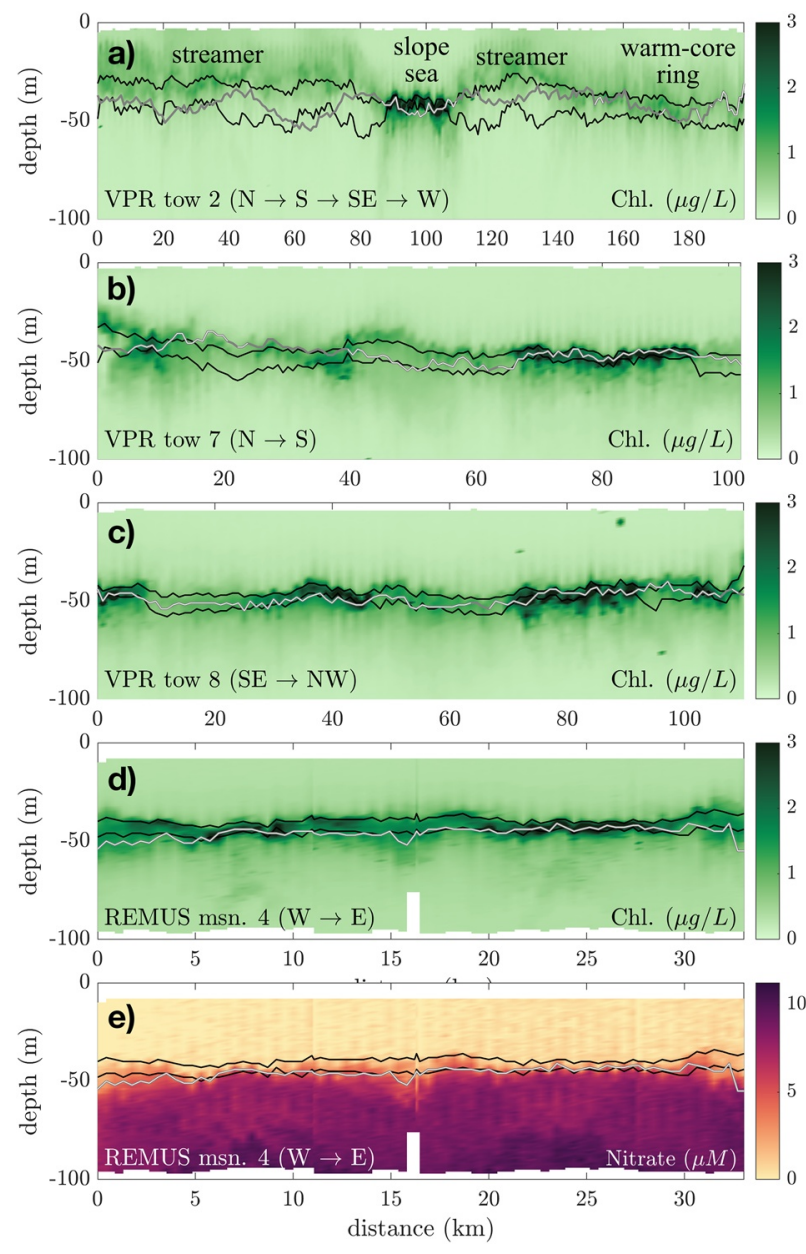

Figure 4. Video Plankton Recorder (a-c) and REMUS (d-e) transects plotted against distance, showing chlorophyll hotspots and elevated nitrate where the $\sigma_{\theta}=26.0 \mathrm{~kg} \mathrm{~m}^{-3}$ isopycnal receives adequate irradiance. $\sigma_{\theta}=26.0 \mathrm{~kg} \mathrm{~m}^{-3}$ isopycnal depth is plotted in white where salinity $>35.6$; gray where fresher. The range of estimated euphotic depth (depth of $1 \%$ light, \pm 1 standard deviation) is shown by black lines.
These diatom hotspots were acclimated to low irradiance levels, and defined by thin peaks of high primary productivity near the euphotic depth. While a depth-resolving bio-optical model (Behrenfeld \& Falkowski, 1997a, 1997b) closely reproduced measured profiles of net productivity at hotspot casts, estimated integrated productivity from deck-board incubations was lower than modeled for hotspots, as the thin Chl maxima were usually missed by discrete water samples (Figure S6). This systematic underestimation of measured integrated productivity was much less for nonhotspot casts, where the bio-optical model slightly underestimated integrated productivity. Profiles of triple oxygen isotopes showed that the hotspots had higher levels of gross primary production than the surrounding waters (Figure S8). The estimated rate of hotspot gross primary production from triple oxygen isotopes at a depth a few meters below the peak $\mathrm{Chl}$ in cast 71 was $48 \mathrm{mg} \mathrm{C} \mathrm{m}^{-3} \mathrm{~d}^{-1}$ - on the same order as estimated by the bio-optical model even though the estimate stems from a completely independent method that measures an integrated average of production in the hotspot over the preceding two weeks.

The deep diatom hotspots were consistently detected at the $\sigma_{\theta}=26.0 \mathrm{~kg}$ $\mathrm{m}^{-3}$ isopycnal (Figure 2d) east of the WCR where there was (a) high salinity water (>35.6), and (b) sufficiently clear overlying water to allow for a deep ( $\sim 50 \mathrm{~m}$ ) subsurface bloom (Figure 4). High Chl could be found where the $\sigma_{\theta}=26.0 \mathrm{~kg} \mathrm{~m}^{-3}$ isopycnal rose above the euphotic depth (the depth of $1 \%$ surface irradiance levels), provided that the salinity at the $\sigma_{\theta}=26.0 \mathrm{~kg} \mathrm{~m}^{-3}$ isopycnal was also of deeper GS origin (>35.6, Figure 4). Within the cyclonic feature (VPR tows 7 and 8, Figure 4), the $\sigma_{\theta}=26.0 \mathrm{~kg}$ $\mathrm{m}^{-3}$ isopycnal was consistently close to $50 \mathrm{~m}$ and near the base of the euphotic zone. Vertical displacement of the isopycnal by only a few meters could therefore result in a hotspot. The higher-resolution REMUS 600 survey of the hotspot conducted on July 12-13 near the shelfbreak (Figure 4) included measurements from a Submersible Ultraviolet Nitrate Analyzer and confirmed elevated nitrate concentrations at the $\sigma_{\theta}=26.0 \mathrm{~kg} \mathrm{~m}^{-3}$ isopycnal. We note that these conditions only held east of the shelf water streamer; high salinity and high Chl hotspots were not detected within the WCR (Figure 4a).

\section{Upwelling of Deep Gulf Stream Water}

The slope sea hotspots were typically observed at $\sim 50 \mathrm{~m}$. At the northern edge of the GS, however, the temperature-salinity signature associated with the slope sea hotspots occurs at $\sim 100 \mathrm{~m}$, about $50 \mathrm{~m}$ deeper than observed in the slope sea (Figure 5). We propose that the upward transport of this deep GS water during its northward intrusion in the MAB slope sea supplied deeper nutrients to the base of the euphotic zone, driving subsurface hotspots.

We tested the plausibility that upwelling of GS water properties could reproduce observations of physical and biogeochemical properties, particularly the high Chl maximum value, at station SLP (Cast 100), the TN368 slope sea station (cyan star in Figure 1c). We applied an upward vertical velocity typical of submesoscale features in the region (e.g., Zhang \& Partida, 2018) to characteristic GS profiles of temperature, salinity, and nutrients. This analysis was performed using a one-dimensional model (Price et al., 1986) of the upper ocean $(0-150 \mathrm{~m})$ coupled to a nitrate-phytoplankton-zooplankton-detritus biogeochemical model (modified from Fennel et al., 2006; Powell et al., 2006). The upward vertical velocity varied linearly with water depth, starting from zero at the sea surface. We applied a maximum vertical velocity at $150 \mathrm{~m}$ of $10^{-4} \mathrm{~m} \mathrm{~s}^{-1}\left(\sim 6 \mathrm{~m} \mathrm{~d}^{-1}\right.$ at $150 \mathrm{~m}$ and $\sim 2 \mathrm{~m} \mathrm{~d}^{-1}$ at $\left.50 \mathrm{~m}\right)$. After 12 days, the model closely matched observations of temperature, salinity, nitrate, and Chl below the surface mixed layer at station SLP (Figure 5a), supporting the plausibility that the observed subsurface hotspots resulted from the upwelling of GS water 

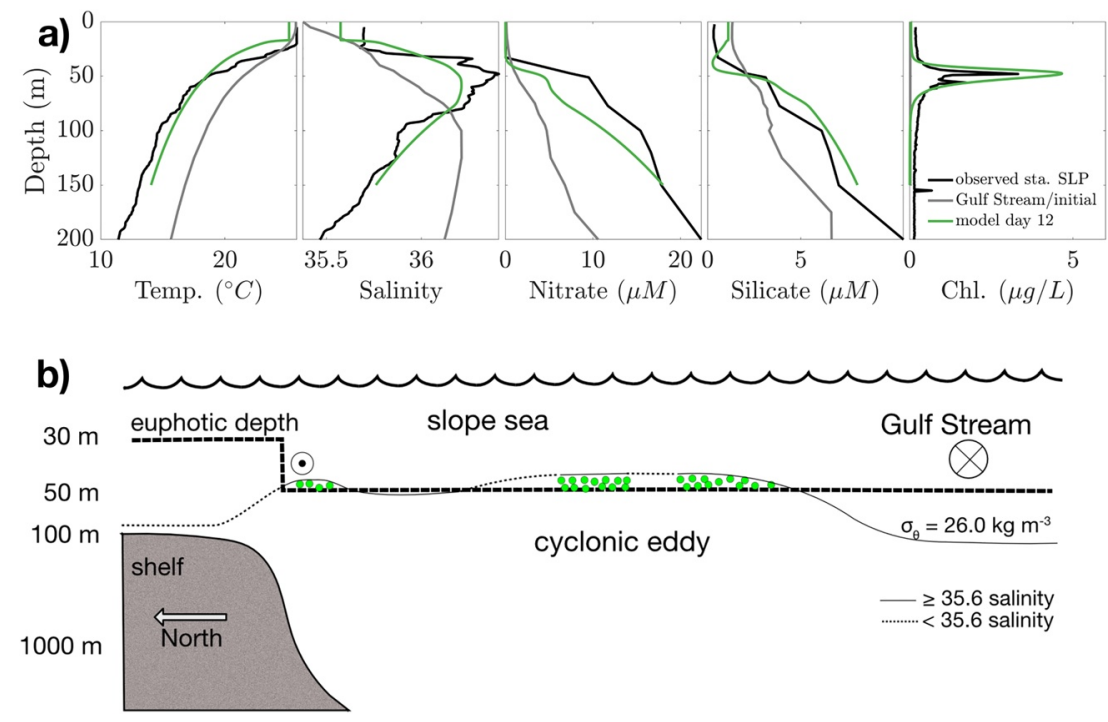

Figure 5. 1D and conceptual models of Gulf Stream water upwelling: (a) 1D model initial profiles (gray) and output at day 12 (green), versus observations from SLP (Cast 100; black); (b) north-south schematic of slope sea hotspots.

from south of the MAB, despite neglecting the horizontal advective mechanisms at play during its transport into the slope sea euphotic zone.

\section{Discussion and Conclusions}

\subsection{Transport Pathways}

Hotspot formation likely occurred shortly before the cruise. As the GS meander moved northeastward toward the shelfbreak, it carried filaments of warm GS water along its western edge (Figure 1b). These filaments may have been transported northward by the cyclonic feature formed in the slope sea (Lee et al., 1991, Figure 1e). This background cyclonic gyre typifies the MAB slope sea (Csanady \& Hamilton, 1988), with the density surface $\sigma_{\theta}=26.0 \mathrm{~kg} \mathrm{~m}^{-3}$ doming to the base of the euphotic zone $(\sim 50 \mathrm{~m})$ in summer regional climatologies of the Northwest Atlantic (Seidov, 2016). Isopycnals are known to shoal at the northern edges of anticyclonic meanders (Bower \& Rossby, 1989), transporting nutrients into the euphotic zone and stimulating phytoplankton growth (Flierl \& Davis, 1993). Upwelling may also have occurred in a divergent flow at the western meander edge (e.g., Hitchcock et al., 1993; Olson et al., 1994). It is thus plausible that GS water was vertically transported along isopycnals and into the euphotic zone during its northward transport by the slope sea cyclonic feature, though a high-resolution $3 \mathrm{D}$ model is required to determine the actual driving mechanism(s).

Surface GS waters are oligotrophic and nutrient-poor; however, nutrient concentrations at depth are greater within the GS relative to the waters of the same isopycnals in the slope sea (Csanady, 1990; Palter \& Lozier, 2008; Pelegri \& Csanady, 1991). Schollaert et al. (2004) suggested the flux of nutrient-rich subsurface waters of the GS could explain interannual variability in the magnitude of the spring bloom in the slope sea; our study shows nutrient supply from the GS influences subsurface summer productivity. Hotspots within the slope sea were generally found where there was slight uplift of the $\sigma_{\theta}=26.0 \mathrm{~kg} \mathrm{~m}^{-3}$ isopycnal into the photic zone (Figures 4a and 4b), which may have driven episodic new production (e.g., Goldman, 1988). Observed water mass characteristics suggest interleaving of slope and GS waters. We thus propose both slope and GS waters were upwelled by isopycnal doming by the cyclonic eddy (Figure 5b; Yoder et al., 1981). Hotspots occurred only in those places where the subsurface GS waters (salinity > 35.6) were sufficiently upwelled to be illuminated (Figure 5). Deformation or stretching of the filaments of GS water generated from baroclinic instability at the meander edge (Figures 1b and 1c) may have also resulted in GS/slope water frontogenesis (Mied et al., 1996; Zhang \& Partida, 2018). The associated upward velocities may have 
enhanced or driven the increased illumination of the nutrient-rich $\sigma_{\theta}=26.0 \mathrm{~kg} \mathrm{~m}^{-3}$ isopycnal (e.g., Lévy et al., 2001; Mahadevan, 2016).

Subsurface Chl hotspots were also observed at the shelf/slope water interface, which was found near the shelfbreak and at the eastern streamer edge. At the shelf/slope water interface the euphotic depth shoals with the transition from clear slope water to turbid shelf water (Figure 4). Consequently, while under shelf water the $\sigma_{\theta}=26.0 \mathrm{~kg} \mathrm{~m}^{-3}$ isopycnal does not receive adequate photosynthetically active radiation to support significant phytoplankton growth (Figure $5 \mathrm{~b}$ ). The hotspots at the streamer edge (Figure 4, VPR transect 2) may have originated near the shelfbreak before being advected southward by the anticyclonic currents at the edge of the WCR along with the shelf water streamer.

\subsection{Implications}

The anomalous subsurface diatom hotspots reached from the shelf edge to the southern and eastern boundaries of our sampling area, and the GS water associated with the hotspots was present in the top $50 \mathrm{~m}$ at $>99 \%$ of VPR slope profiles (Figure 2). It is therefore probable that our snapshot observations did not capture the full extent of the diatom hotspots in the slope sea. The hotspots were anomalous relative to the summer slope sea Chl climatology, but similar high-salinity, high-Chl events may not be uncommon in the region: Such events were recorded by summer glider measurements from the Ocean Observatories Initiative (OOI) Pioneer Array (Trowbridge et al., 2019) in three of the past 5 years in the MAB slope sea (Figure S10). During the 2 years where such an event was not captured by gliders (2017 and 2018), the shelfbreak front extended south of the glider area, and slope water was not measured. High-salinity, high-Chl events could still have occurred in the slope sea during these periods. A shoaling nutricline giving rise to episodic diatom-dominated new production at low light has also been well documented in other parts of the ocean (e.g., Goldman, 1988; Goldman \& McGillicuddy, 2003); our observations suggest this potential mechanism in the MAB slope sea corresponded with the intrusion of GS water. Given that GS intrusions have become more frequent and persistent in recent decades, these subsurface hotspots may be important when considering the integrated effects of changing North Atlantic circulation on regional ecosystems and carbon export.

Western boundary current systems worldwide have shown shifting trends. For example, increasing instability has been documented for the East Australian Current (Sloyan et al., 2016) and Agulhas Current (Beal \& Elipot, 2016), and the Kuroshio Extension undergoes decadal shifts between stable and unstable states (Qiu \& Chen, 2010). To understand the influence of changing western boundary currents on marine ecosystems, we must unravel the mechanisms by which meanders, WCRs, and other intrusions influence light and nutrient conditions for both surface and subsurface phytoplankton growth. Assessing the long-term trajectory of primary productivity with respect to an increasingly meandering western boundary current will require a deeper mechanistic understanding of the phenomena described in this study, for which further and persistent subsurface observations and process-oriented coupled physical-biogeochemical modeling are needed. Continued monitoring of the slope sea by the OOI Pioneer Array offshore moorings, gliders, and autonomous underwater vehicles will be key to achieving this understanding. Finally, this study highlights the potential for disparate regional impacts of changing large-scale circulation on marine ecosystems: Whereas our findings suggests that direct interaction of the GS with the continental shelf and slope could drive enhanced productivity at the Chl maximum in the subtropical Atlantic, a slower nutrient steam could suppress subarctic primary productivity in future climate scenarios (Whitt \& Jansen, 2020).

\section{Data Availability Statement}

All CTD, VPR, and bottle fields are archived at the SPIROPA project page at the Biological \& Chemical Oceanography Data Management Office (BCO-DMO) with DOIs 10.26008/1912/bco-dmo.807119.2, 10.26008/1912/bco-dmo.848898.1, and 10.26008/1912/bco-dmo.849340.1. SPIROPA IFCB images are available at https://ifcb-data.whoi.edu/timeline?dataset=SPIROPA. Amplicon sequence variants read counts are included in Data-set S1. 
Acknowledgments

This research was supported by the National Science Foundation (OCE1657803 and OCE-1657855) and the Dalio Explorer Fund. H. Oliver was supported by a WHOI Postdoctoral Scholar award. We thank Jeff Turner and Chrissy Petitpas for their work on higher trophic levels, Fred Thwaites and Josh Eaton for VPR operations, Mike Purcell, Gwyneth Packard, and Judson Poole for REMUS surveys, Taylor Crockford for IFCB operations, Emily Peacock for contributing to IFCB image classification, Meredith Meyer for contributions to productivity data analysis, Frannie Adams, Lumi Kinjo, Erin Kim, and Zoe Sandwith for contributing to triple oxygen isotope data collection and analysis, and Sophie Clayton for her thoughts on our modeling approach, as well as our SPIROPA colleagues and crew of the $R / V$ Thomas $G$. Thompson for their assistance and support at sea.

\section{References}

Andres, M. (2016). On the recent destabilization of the Gulf Stream path downstream of Cape Hatteras. Geophysical Research Letters, 43(18), 9836-9842. https://doi.org/10.1002/2016GL069966

Beal, L. M., \& Elipot, S. (2016). Broadening not strengthening of the Agulhas Current since the early 1990s. Nature, 540(7634), 570-573. https://doi.org/10.1038/nature19853

Behrenfeld, M. J., \& Falkowski, P. G. (1997a). A consumer's guide to phytoplankton primary productivity models. Limnology and Oceanography, 42(7), 1479-1491. https://doi.org/10.4319/lo.1997.42.7.1479

Behrenfeld, M. J., \& Falkowski, P. G. (1997b). Photosynthetic rates derived from satellite-based chlorophyll concentration. Limnology and Oceanography, 42(1), 1-20. https://doi.org/10.4319/lo.1997.42.1.0001

Bower, A. S., \& Rossby, T. (1989). Evidence of cross-frontal exchange processes in the Gulf Stream based on isopycnal RAFOS float data. Journal of Physical Oceanography, 19(9), 1177-1190. https://doi.org/10.1175/1520-0485(1989)019<1177:eocfep >2.0.co;2

Brown, O. B., Evans, R. H., Brown, J. W., Gordon, H. R., Smith, R. C., \& Baker, K. S. (1985). Phytoplankton blooming off the U.S. East coast: A satellite description. Science, 229(4709), 163-167. https://doi.org/10.1126/science.229.4709.163

Csanady, G. T. (1990). Physical basis of coastal productivity: The SEEP and MASAR experiments. Eos, Transactions American Geophysical Union, 71(36), 1060-1065. https://doi.org/10.1029/EO071i036p01060

Csanady, G. T., \& Hamilton, P. (1988). Circulation of slopewater. Continental Shelf Research, 8(5-7), 565-624. http://dx.doi. org/10.1016/0278-4343(88)90068-4

Cullen, J. J. (2015). Subsurface chlorophyll maximum layers: Enduring enigma or mystery solved? Annual Review of Marine Science, 7(1), 207-239. https://doi.org/10.1146/annurev-marine-010213-135111

Fennel, K., \& Boss, E. (2003). Subsurface maxima of phytoplankton and chlorophyll: Steady-state solutions from a simple model. Limnology and Oceanography, 48(4), 1521-1534. https://doi.org/10.4319/lo.2003.48.4.1521

Fennel, K., Wilkin, J., Levin, J., Moisan, J., O'Reilly, J., \& Haidvogel, D. (2006). Nitrogen cycling in the Middle Atlantic Bight: Results from a three-dimensional model and implications for the North Atlantic nitrogen budget. Global Biogeochemical Cycles, 20(3), 1-14. https:// doi.org/10.1029/2005GB002456

Flierl, G. R., \& Davis, C. S. (1993). Biological effects of Gulf Stream meandering. Journal of Marine Research, 51(3), 529-560. https://doi. org/10.1357/0022240933224016

Friedrichs, M. A. M., St-Laurent, P., Xiao, Y., Hofmann, E., Hyde, K., Mannino, A., et al. (2019). Ocean circulation causes strong variability in the Mid-Atlantic Bight nitrogen budget. Journal of Geophysical Research: Oceans, 124, 113-134. https://doi.org/10.1029/2018JC014424

Fryxell, G. A., Gould, R. W., \& Watkins, T. P. (1984). Gelatinous colonies of the diatom Thalassiosira in Gulf Stream Warm Core Rings including T. fragilis, sp. nov. British Phycological Journal, 19(2), 141-156. https://doi.org/10.1080/00071618400650151

Gangopadhyay, A., Gawarkiewicz, G., Silva, E. N. S., Monim, M., \& Clark, J. (2019). An observed regime shift in the formation of warm core rings from the Gulf Stream. Scientific Reports, 9(1), 1-9. https://doi.org/10.1038/s41598-019-48661-9

Gawarkiewicz, G., Todd, R. E., Zhang, W., Partida, J., Gangopadhyay, A., Monim, M. U. H., et al. (2018). The changing nature of shelf-break exchange revealed by the OOI Pioneer Array. Oceanography, 31(1), 60-70. https://doi.org/10.5670/oceanog.2018.110

Gawarkiewicz, G. G., Todd, R. E., Plueddemann, A. J., Andres, M., \& Manning, J. P. (2012). Direct interaction between the Gulf Stream and the shelfbreak south of New England. Scientific Reports, 2(1), 553. https://doi.org/10.1038/srep00553

Goldman, J. C. (1988). Spatial and Temporal Discontinuities of Biological Processes in Pelagic Surface Waters. In B. J. Rothschild (Ed.), Toward a Theory on Biological-Physical Interactions in the World Ocean (pp. 273-296). Dordrecht: Springer Netherlands. https://doi. org/10.1007/978-94-009-3023-0_15

Goldman, J. C., \& McGillicuddy, D. J. (2003). Effect of large marine diatoms growing at low light on episodic new production. Limnology and Oceanography, 48(3), 1176-1182. https://doi.org/10.4319/lo.2003.48.3.1176

Hitchcock, G. L., Mariano, A. J., \& Rossby, T. (1993). Mesoscale pigment fields in the Gulf Stream: Observations in a meander crest and trough. Journal of Geophysical Research, 98(5), 8425-8445. https://doi.org/10.1029/92jc02911

Lee, T. N., Yoder, J. A., \& Atkinson, L. P. (1991). Gulf Stream frontal eddy influence on productivity of the southeast US Continental Shelf. Journal of Geophysical Research, 96(C12), 191-205. https://doi.org/10.1029/91jc02450

Lévy, M., Klein, P., \& Treguier, A. M. (2001). Impact of sub-mesoscale physics on production and subduction of phytoplankton in an oligotrophic regime. Journal of Marine Research, 59(4), 535-565. https://doi.org/10.1357/002224001762842181

Mahadevan, A. (2016). The impact of submesoscale Physics on primary productivity of plankton. Annual Review of Marine Science, 8(1), 161-184. https://doi.org/10.1146/annurev-marine-010814-015912

Mied, R. P., Shen, C. Y., Evans, T. E., \& Lindemann, G. J. (1996). Frontogenesis with ageostrophic vertical shears and horizontal density gradients: Gulf Stream meanders onto the continental shelf. Journal of Geophysical Research, 101(C8), 18079-18104. https://doi. org/10.1029/96JC01423

Morgan, C. W., \& Bishop, J. M. (1977). An example of gulf stream eddy-induced water exchange in the Mid-Atlantic Bight. Journal of Physical Oceanography, 7, 472-479. https://doi.org/10.1175/1520-0485(1977)007<0472:AEOGSE >2.0.CO;2

Nof, D. (1983). On the migration of isolated eddies with application to Gulf Stream rings. Journal of Marine Research, 41(3), 399-425. https://doi.org/10.1357/002224083788519687

Olson, D., Hitchcock, G., Mariano, A., Ashjian, C., Peng, G., Nero, R., \& Podesta, G. (1994). Life on the edge: Marine life and fronts. Oceanography, 7(2), 52-60. https://doi.org/10.5670/oceanog.1994.03

O'Reilly, J. E., \& Busch, D. A. (1984). Phytoplankton primary production on the northwestern Atlantic shelf. Rapports et Proces-Verbaux des Reunions Consell International pour I'Exploration de la Mer, 183, 255-268.

O'Reilly, J. E., Evans-Zetlin, C., \& Busch, D. A. (1987). Primary production. In R. H. Backus, \& D. W. Bourne (Eds.), Georges bank (p. 220-233). Cambridge, MA. MIT Press.

O'Reilly, J. E., \& Zetlin, C. (1998), Season, horizontal, and vertical distribution of phytoplankton chlorophyll a in the northeast U.S. continental shelf ecosystem, NOAA Technical Rep. NMFS, 139, (pp. 119). Seattle, Washington: NOAA, US Department of Commerce.

Palter, J. B., \& Lozier, M. S. (2008). On the source of Gulf Stream nutrients. Journal of Geophysical Research, 113, C06018. https://doi. org/10.1029/2007JC004611

Pelegri, J. L., \& Csanady, G. T. (1991). Nutrient transport and mixing in the gulf stream. Journal of Geophysical Research, 96(C2), 25772583. https://doi.org/10.1029/90JC02535

Powell, T. M., Lewis, C. V. W. W., Curchitser, E. N., Haidvogel, D. B., Hermann, A. J., \& Dobbins, E. L. (2006). Results from a three-dimensional, nested biological-physical model of the California Current System and comparisons with statistics from satellite imagery. Journal of Geophysical Research, 111, 1-14. https://doi.org/10.1029/2004JC002506 
Price, J. F., Weller, R. A., \& Pinkel, R. (1986). Diurnal cycling: Observations and models of the upper ocean response to diurnal heating, cooling, and wind mixing. Journal of Geophysical Research, 91(C7), 8411-8427. https://doi.org/10.1029/JC091iC07p08411

Qiu, B., \& Chen, S. (2010). Eddy-mean flow interaction in the decadally modulating Kuroshio Extension system. Deep Sea Research Part II: Topical Studies in Oceanography, 57(13-14), 1098-1110. https://doi.org/10.1016/j.dsr2.2008.11.036

Ryan, J. P., Yoder, J. A., \& Cornillon, P. C. (1999). Enhanced chlorophyll at the shelfbreak of the Mid-Atlantic Bight and Georges Bank during the spring transition. Limnology and Oceanography, 44(1), 1-11. https://doi.org/10.4319/lo.1999.44.1.0001

Schollaert, S. E., Rossby, T., \& Yoder, J. A. (2004). Gulf Stream cross-frontal exchange: Possible mechanisms to explain interannual variations in phytoplankton chlorophyll in the Slope Sea during the SeaWiFS years. Deep Sea Research Part II: Topical Studies in Oceanography, 51(1), 173-188. https://doi.org/10.1016/j.dsr2.2003.07.017

Seidov, D., Baranova, O. K., Boyer, T. P., Cross, S. L., Mishonov, A. V., \& Parsons, A. R. (2016). Northwest Atlantic Regional Climatology (NCEI Accession 0155889) (pp. 1-56). NOAA National Centers for Environmental Information. https://doi.org/10.7289/v5rf5s2q

Sherman, K., Jaworski, N. A., \& Smayda, T. J. (1996). The Northeast shelf ecosystem: Assessment, sustainability and management. Cambridge, MA, USA. Blackwell Science, Inc.

Sloyan, B. M., Ridgway, K. R., \& Cowley, R. (2016). The East Australian Current and property transport at $27^{\circ}$ S from 2012 to 2013. Journal of Physical Oceanography, 46(3), 993-1008. https://doi.org/10.1175/JPO-D-15-0052.1

Trowbridge, J., Weller, R., Kelley, D., Dever, E., Plueddemann, A., Barth, J. A., \& Kawka, O. (2019). The ocean observatories initiative. Frontiers in Marine Science, 6(MAR), 1-23. https://doi.org/10.3389/fmars.2019.00074

Whitt, D. B., \& Jansen, M. F. (2020). Slower nutrient stream suppresses Subarctic Atlantic Ocean biological productivity in global warming. Proceedings of the National Academy of Sciences of the United States of America, 117(27), 15504-15510. https://doi.org/10.1073/ pnas.2000851117

Xu, Y., Chant, R., Gong, D., Castelao, R., Glenn, S., \& Schofield, O. (2011). Seasonal variability of chlorophyll a in the Mid-Atlantic Bight. Continental Shelf Research, 31(16), 1640-1650. https://doi.org/10.1016/j.csr.2011.05.019

Yoder, J. A., Atkinson, L. P., Lee, T. N., Kim, H. H., \& McClain, C. R. (1981). Role of Gulf Stream frontal eddies in forming phytoplankton patches on the outer southeastern shelf. Limnology and Oceanography, 26(6), 1103-1110. https://doi.org/10.4319/lo.1981.26.6.1103

Zhang, W. G., \& Gawarkiewicz, G. G. (2015). Dynamics of the direct intrusion of Gulf Stream ring water onto the Mid-Atlantic Bight shelf. Geophysical Research Letters, 42, 7687-7695. https://doi.org/10.1002/2015GL065530

Zhang, W. G., McGillicuddy, D. J., \& Gawarkiewicz, G. G. (2013). Is biological productivity enhanced at the New England shelfbreak front? Journal of Geophysical Research: Oceans, 118, 517-535. https://doi.org/10.1002/jgrc.20068

Zhang, W. G., \& Partida, J. (2018). Frontal subduction of the Mid-Atlantic Bight Shelf Water at the onshore edge of a warm-core ring. Journal of Geophysical Research: Oceans, 123, 7795-7818. https://doi.org/10.1029/2018JC013794

\section{References From the Supporting Information}

Altschul, S. F., Gish, W., Miller, W., Myers, E. W., \& Lipman, D. J. (1990). Basic local alignment search tool. Journal of Molecular Biology, 215(3), 403-410. https://doi.org/10.1016/S0022-2836(05)80360-2

Bray, J. R., \& Curtis, J. T. (1957). An ordination of the upland forest communities of Southern Wisconsin. Ecological Monographs, 27(4), 325-349. https://doi.org/10.2307/1942268

Brzezinski, M. A. (2004). The Si:C:N Ratio of Marine Diatoms: Interspecific Variability and the Effect of some Environmental Variables. Journal of Phycology, 21(3), 347-357. https://doi.org/10.1111/j.0022-3646.1985.00347.x

Callahan, B. J., McMurdie, P. J., Rosen, M. J., Han, A. W., Johnson, A. J. A., \& Holmes, S. P. (2016). DADA2: High-resolution sample inference from Illumina amplicon data. Nature Methods, 13(7), 581-583. https://doi.org/10.1038/nmeth.3869

Chappell, P. D., Virginia Armbrust, E., Barbeau, K. A., Bundy, R. M., Moffett, J. W., Vedamati, J., \& Jenkins, B. D. (2019). Patterns of diatom diversity correlate with dissolved trace metal concentrations and longitudinal position in the northeast Pacific coastal-offshore transition zone. Marine Ecology Progress Series, 609, 69-86. https://doi.org/10.3354/meps12810

Clarke, K. R., \& Gorley, R. N. (2018). Getting started with PRIMER v7. Primer-E, (1), 20. https://doi.org/10.22201/ib.20078706e.2018.3.2409

Davis, C. S., Thwaites, F. T., Gallager, S. M., Hu, Q., Naiman, M., Sutton, T., et al. (2005). A three-axis fast-tow digital Video Plankton Recorder for rapid surveys of plankton taxa and hydrography. Limnology and Oceanography, 3, 59-74. https://doi.org/10.4319/lom.2005.3.59

Fasham, M. J. R., Ducklow, H. W., \& McKelvie, S. M. (1990). A nitrogen-based model of plankton dynamics in the oceanic mixed layer. Journal of Marine Research, 48(3), 591-639. https://doi.org/10.1357/002224090784984678

Friedrichs, M. A. M., Carr, M. E., Barber, R. T., Scardi, M., Antoine, D., Armstrong, R. A., et al. (2009). Assessing the uncertainties of model estimates of primary productivity in the tropical Pacific Ocean. Journal of Marine Systems, 76(1-2), 113-133. https://doi.org/10.1016/j. jmarsys.2008.05.010

Garcia, H., Weathers, K. W., Paver, C. R., Smolyar, I., Boyer, T. P., Locarnini, R. A., et al. (2019). World Ocean Atlas 2018. Vol. 4: Dissolved inorganic nutrients (phosphate, nitrate and nitrate+nitrite, silicate). NOAA Atlas NESDIS 82, 4(July) (p. 35).

González, P., Castaño, A., Peacock, E. E., Díez, J., del Coz, J. J., \& Sosik, H. M. (2019). Automatic plankton quantification using deep features. Journal of Plankton Research, 41(4), 449-463. https://doi.org/10.1093/plankt/fbz023

Hendricks, M. B., Bender, M. L., \& Barnett, B. A. (2004). Net and gross $\mathrm{O}_{2}$ production in the Southern Ocean from measurements of biological $\mathrm{O}_{2}$ saturation and its triple isotope composition. Deep-Sea Research Part I: Oceanographic Research Papers, 51(11), 1541-1561. https://doi.org/10.1016/j.dsr.2004.06.006

Holmes, R. M., Aminot, A., Kérouel, R., Hooker, B. A., \& Peterson, B. J. (1999). A simple and precise method for measuring ammonium in marine and freshwater ecosystems. Canadian Journal of Fisheries and Aquatic Sciences, 56(10), 1801-1808. https://doi.org/10.1139/ f $99-128$

Jassby, A. D., \& Platt, T. (1976). Mathematical formulation of the relationship between photosynthesis and light for phytoplankton. Limnology and Oceanography, 21(4), 540-547. https://doi.org/10.4319/lo.1976.21.4.0540

Joyce, T. M., Deser, C., \& Spall, M. A. (2000). The relation between decadal variability of subtropical mode water and the North Atlantic Oscillation. Journal of Climate, 13(14), 2550-2569. https://doi.org/10.1175/1520-0442(2000)013<2550:TRBDVO>2.0.CO;2

Juranek, L. W., \& Quay, P. D. (2013). Using triple isotopes of dissolved oxygen to evaluate global marine productivity. Annual Review of Marine Science, 5(1), 503-524. https://doi.org/10.1146/annurev-marine-121211-172430

Kaiser, J. (2011). Technical note: Consistent calculation of aquatic gross production from oxygen triple isotope measurements. Biogeosciences, 8(7), 1793-1811. https://doi.org/10.5194/bg-8-1793-2011 
Kalnay, E., Kanamitsu, M., Kistler, R., Collins, W., Deaven, D., Gandin, L., et al. (1996). The NCEP/NCAR 40-year reanalysis project. Bulle tin of the American Meteorological Society, 77(3), 437-471. https://doi.org/10.1175/1520-0477(1996)077<0437:tnyrp>2.0.co;2

Luz, B., \& Barkan, E. (2000). Assessment of oceanic productivity with the triple-isotope composition of dissolved oxygen. Science, 288(5473), 2028-2031. https://doi.org/10.1126/science.288.5473.2028

Luz, B., \& Barkan, E. (2005). The isotopic ratios $17 \mathrm{O} / 16 \mathrm{O}$ and 180/160 in molecular oxygen and their significance in biogeochemistry. Geochimica et Cosmochimica Acta, 69(5), 1099-1110. https://doi.org/10.1016/j.gca.2004.09.001

Martin, M. (2011). Cutadapt removes adapter sequences from high-throughput sequencing reads. EMBnet.Journal, 17(1), 10-12. https:// doi.org/10.14806/ej.17.1.200

Moberg, E. A., \& Sosik, H. M. (2012). Distance maps to estimate cell volume from two-dimensional plankton images. Limnology and Oceanography, 10(4), 278-288. https://doi.org/10.4319/lom.2012.10.278

Morel, A. (1974). Optical properties of pure water and pure sea water. Optical Aspects of Oceanography, 1, 1-24.

Platt, T., \& Jassby, A. D. (1976). The relationship between photosynthesis and light for natural assemblages of coastal marine phytoplankton. Journal of Phycology, 12(4), 421-430. https://doi.org/10.1111/j.1529-8817.1976.tb02866.x

Prokopenko, M. G., Pauluis, O. M., Granger, J., \& Yeung, L. Y. (2011). Exact evaluation of gross photosynthetic production from the oxygen triple-isotope composition of $\mathrm{O} 2$ : Implications for the net-to-gross primary production ratios. Geophysical Research Letters, 38, 1-5. https://doi.org/10.1029/2011GL047652

Redfield, A. C. (1963). The influence of organisms on the composition of sea-water. The sea, 2, 26-77.

Siegel, D. A., Doney, S. C., \& Yoder, J. A. (2002). The North Atlantic spring phytoplankton bloom and Sverdrup's critical depth hypothesis. Science, 296(5568), 730-733. https://doi.org/10.1126/science.1069174

Sosik, H. M., \& Olson, R. J. (2007). Automated taxonomic classification of phytoplankton sampled with imaging-in-flow cytometry. Limnology and Oceanography, 5(6), 204-216. https://doi.org/10.4319/lom.2007.5.204

Sosik, H. M., Peacock, E., \& Santos, M. (2020). Abundance and biovolume of taxonomically-resolved phytoplankton and microzooplankton imaged continuously underway with an Imaging FlowCytobot along the NES-LTER Transect in winter 2018 ver 1. Retrieved from https:// doi.org/10.6073/pasta/74775c4af51c237f2a20e4a8c011bc53

Stanley, R. H. R., Kirkpatrick, J. B., Cassar, N., Barnett, B. A., \& Bender, M. L. (2010). Net community production and gross primary production rates in the western equatorial Pacific. Global Biogeochemical Cycles, 24(4), 1-17. https://doi.org/10.1029/2009GB003651

Zimmermann, J., Jahn, R., \& Gemeinholzer, B. (2011). Barcoding diatoms: Evaluation of the V4 subregion on the 18S rRNA gene, including new primers and protocols. Organisms Diversity \& Evolution, 11(3), 173-192. https://doi.org/10.1007/s13127-011-0050-6 